\title{
Buserelin Acetate Reduces Mortality and DNA Defragmentation of Bovine Sperm Cells Exposed to Oxidative Stress
}

\author{
Alicja Kowalczyk ${ }^{1}$, Marian Kuczaj ${ }^{2}$, Anna Szul ${ }^{3}$ and Ewa Czerniawska-Piątkowska ${ }^{4 *}$ \\ ${ }^{1}$ Wroctaw University Of Environmental and Life Sciences, Department of Environment, \\ Animal Hygiene and Welfare, Chetmońskiego 38C, Wrocław \\ ${ }^{2}$ Wroctaw University Of Environmental and Life Sciences, Institute of Animal Breeding, \\ Chetmońskiego 38C, Wroctaw \\ ${ }^{3}$ Malopolska Biotechnic Centre Ltd, Krasne 32 \\ ${ }^{4}$ Department of Animal Reproduction Biotechnology and Environmental Hygiene West \\ Pomeranian University of Technology in Szczecin, ul. Klemensa Janickiego 29, 71-270 \\ Szczecin, Poland
}

\begin{abstract}
A B S T R A C T
The aim of this study was to examine the effect of the GnRH analogue (buserelin acetate) on the quality of frozen-thawed bovine spermatozoa. In this study, ten Polish Holstein-Friesian bulls with an average age of $3.5 \pm 0.5$ years were housed individually in pens. From each bull, two ejaculates were collected using an artificial vagina. Semen samples that showed more than $60 \%$ motility and $60 \%$ viability were selected for this experiment. To the four diluted samples were added $0 \mu \mathrm{g} / \mathrm{mL}$ successively; $2 \mu \mathrm{g} / \mathrm{mL} ; 4 \mu \mathrm{g} /$ $\mathrm{mL}$ and $8 \mu \mathrm{g} / \mathrm{mL}$ buserelin acetate (Buserelin ${ }^{\circledR}$ aniMedica, Poland). After equilibration, the straws were frozen in liquid nitrogen vapour using a computer controlled automatic freezer. After one day, straws were thawed in a water bath at $38^{\circ} \mathrm{C}$ for $20 \mathrm{sec}$ and then were examined. Semen analysis included viability, DNA defragmentation and motility of spermatozoa were being estimated. The addition of $2 \mu \mathrm{g} / \mathrm{mL}$ of the GnRH analogue significantly $(P<0.05)$ improved the percentage of live spermatozoa compared to the control group. Samples with supplemented of 2 i $4 \mu \mathrm{g} / \mathrm{mL}$ of buserelin has a significant positive influence on percentage of motile sperm, progressive motility and DNA damage. Improving the quality of frozen semen due to the use of GnRH analogue additive (buserelin acetate) for bovine semen and its low cost of use in routine semen production will allow manufacturers of insemination doses to improve the quality of their product.
\end{abstract}

Article Information
Received 26 June 2019
Revised 30 July 2019
Accepted 17 September 2019
Available online 15 May 2020
Authors' Contribution
AK the initiated the study, conducted
main experimental part, described
the results and wrote the article.
MK participated in collecting the
research material. AS performed the
statistical calculations, participated in
the drafting of the manuscript. ECP
supervised the work.
Key words
Bovine, Buserelin acetate,
Cryoconservation, Oxidative stress,
Spermatozoa

\section{INTRODUCTION}

$\mathrm{G}$ onadotropin-releasing hormone $(\mathrm{GnRH})$ plays a pivotal role in domestic animals reproduction and its analogues are used on a large scale in the treatment of hormone-dependent diseases and assisted reproductive biotechnology. So far, fourteen structural variants and three different forms of $\mathrm{GnRH}$, named as hypothalamic $\mathrm{GnRH}$ or GnRH-I, midbrain GnRH or GnRH-II and GnRH-III across various species of protochordates and vertebrates are known. Interest in research on the physiological, cell biological and function molecular of the hormones appeared along with the growing clinical application of

\footnotetext{
Corresponding author: ewa.czerniawska-piatkowska@ zut.edu.pl 0030-9923/2020/0005-1795 \$ 9.00/0

Copyright 2020 Zoological Society of Pakistan
}

GnRH analogues. These studies are aimed at broadening knowledge and enhance our understanding of the entire system and for the optimal application of analogue therapies.

The availability of GnRH analogues and the possibility of their use in herds has become a powerful tool in the history of controlled reproduction. They are successfully used in the protocol of synchronization of ovulation in dairy cows (Souza et al., 2009), and the popularity of their use is continually growing, as the popularity of embryo-transfer increases. Research indicates a significant improvement in the conception rate (Garcia-Ispierto et al., 2012, 2013a), beneficial effects of using GnRH analogues can also be observed in cows in a weaker condition (BCS) (Souza et al., 2009), in the anestrus phase (Garcia-Ispierto et al., 2012) or under conditions of heat stress (GarciaIspierto et al., 2012, 2013b).

GnRH analogues can also be successfully used in 
inhibiting reproductive functions. This is especially useful for mares that are used in sports. In order to eliminate the oestrus symptoms (including hyperactivity and aggressiveness) and to inhibit (reversible) ovarian function in mare Schulman et al. (2012), they administered GnRH injections.

In other species (rabbits), the effect of the GnRH analogue on sperm quality was examined. Gonadoliberyne was mixed with ejaculate in order to induce ovulation in females (Gogol, 2015, 2016), then the effect of the used product on the quality of male spermatozoa was examined (Gogol et al., 2014).

Constantly growing standards for the freezing of bull semen in insemination centers, caused by dynamically developing competition on the market, affect the need to improve the production technology of insemination doses. Science and practice are constantly looking for new tools and technologies to obtain a straw with sperm with the highest (competitive) quality parameters. In this study, an assessment was made of the effect of the GnRH analogue (buserelin acetate) on the quality of frozen-thawed bovine semen.

\section{MATERIALS AND METHODS}

These experiments have been made as part of routine activities during the current semen production in the reproductive station and did not require the approval of the ethics committee. These experiments were performed on the Breeding and Insemination Centre "MCB" (Krasne, Poland). In this study, ten Polish Holstein-Friesian bulls with an average age of $3.5 \pm 0.5$ years were housed individually in pens. Animals were fed the same (hay, haylage, straw, microelements)

From each bull, two ejaculates were collected using an artificial vagina at 7 a.m. The semen was held in a water bath at $37{ }^{\circ} \mathrm{C}$ while the sperm concentration and initial percentage of motile sperm were being estimated. Sperm concentration was assessed using a digital photometer (Dr Lange, LP 300 SDM; Minitube, Tiefenbach b. Landshut, Germany) at $560 \mathrm{~nm}$.

\section{Semen processing}

Semen samples were immediately transferred into graduated test tubes after collection, placed in a water bath at $37^{\circ} \mathrm{C}$. The fresh undiluted semen was then microscopically (Nikon E 200, China) evaluated for mass motility, percent motile sperm, progressive motility, viability and abnormality spermatozoa. Semen samples that showed more than $60 \%$ motility and $60 \%$ viability were selected for this experiment. After a positive evaluation, semen samples were pooled to eliminate individual differences. Then, in four centrifuge tubes thoroughly placed $1 \mathrm{~mL}$ of fresh semen. Seminal plasma was removed by centrifugation at $700 \mathrm{rcf}$ for $4 \mathrm{~min}$. The remaining fraction was diluted with animal protein-free commercial BIOXcell ${ }^{\circledR}$ extender (IMV Technologies, L'aigle, France) to the final concentration of $120 \times 10^{6}$ spermatozoa $/ \mathrm{mL}$.

To the four diluted samples were added $0 \mu \mathrm{g} / \mathrm{mL}$ successively; $2 \mu \mathrm{g} / \mathrm{mL} ; 4 \mu \mathrm{g} / \mathrm{mL}$ and $8 \mu \mathrm{g} / \mathrm{mL}$ buserelin acetate (Buserelin ${ }^{\circledR}$ aniMedica, Poland). Semen samples were automatically packed (Bloc Machine FIN, IS 4, France) into polyvinyl chloride (PVC) straws $(0.25 \mathrm{~mL})$ (Biovet, France) were filled and equilibrated for $1.5 \mathrm{~h}$ at $4^{\circ} \mathrm{C}$. After equilibration, the straws were frozen in liquid nitrogen vapour using a computer controlled automatic freezer from $4^{\circ} \mathrm{C}$ to $-15^{\circ} \mathrm{C}$ at the rate of $-3^{\circ} \mathrm{C} / \mathrm{min}$ and from $-15^{\circ} \mathrm{C}$ to $-80^{\circ} \mathrm{C}$ at the rate of $-10^{\circ} \mathrm{C} / \mathrm{min}$ (IMV Technologies, France).

After reaching $-80^{\circ} \mathrm{C}$, semen straws were plunged into liquid nitrogen and packaged in plastic goblets for 24 hours of storage in the liquid nitrogen container.

After one day, straws were thawed in a water bath at $38^{\circ} \mathrm{C}$ for $20 \mathrm{sec}$ and then were examined.

\section{Viability}

The double stain SYBR-14 with propidium iodide (L-7011 LIVE/DEAD Sperm Viability Kit; Invitrogen, Molecular Probes, Barcelona, Spain) using flow cytometer was applied (CytoFlex Beckman Coulter, B3-R1-V0, China). To this end, $50 \mu \mathrm{L}$ semen was measured and $940 \mu \mathrm{L}$ $\mathrm{NaCl}(0.9 \%)$ and $5 \mu \mathrm{L} \mathrm{SYBR} 14$ were added. Thoroughly mixed. Then incubated $\left(36^{\circ} \mathrm{C}\right.$ for $\left.10 \mathrm{~min}\right)$ without light. Subsequently, $5 \mu \mathrm{L}$ of PI was remixed and incubated $3 \mathrm{~min}$ without light, followed by a test.

\section{Computerized assessment}

Sperm motility was examined using a Sperm Class Analyzer (SCA, version 5.4, Microptic, Barcelona, Spain), a light microscope (Nikon Eclipse E200), with a x10 negative phase objective, a Basler camera (scA 780-54fc, Ahrensburg, Germany), a warm stage and a computer to analyze and save data. The following sets were used: medium VAP-50.0 $\mu \mathrm{m} \mathrm{s}-1$; low VAP-10 $\mu \mathrm{m} \mathrm{s}-1$; low LIN$50.0 \%$. Before analysis, semen was diluted 1:20 in a warm $\left(26^{\circ} \mathrm{C}\right)$ physiological solution $(0.9 \% \mathrm{NaCl})$. Then $2 \mu \mathrm{L}$ of the prepared sample was placed in a Leja 4 analysis chamber (Leja Products B.V., Holland). The slide was mounted on a stage warmer set at $38^{\circ} \mathrm{C}$. The following motility parameters were included in this study: the percentage of motile sperm and progressive motility. Minimum 1000 cells were evaluated, and depending on sperm concentration, three to five analyses were performed per sample. 


\section{Assessment of sperm DNA integrity}

To further analyze the sperm DNA integrity, chromatin susceptibility to acid-induced denaturation in situ was assessed. The chromatin instability was then quantified by flow cytometric (CytoFlex Beckman Coulter, B3-R1-V0, China) was used Sperm Chromatin Structure Assay (SCSA) test. The samples were thawed in a water bath (26 ${ }^{\circ} \mathrm{C}$ for $30 \mathrm{sec}$.). $13 \mu \mathrm{L}$ of semen and $487 \mu \mathrm{L}$ of $\mathrm{NaCl}$ $(0,9 \%)$ were placed in a glass tube on ice. $50 \mu \mathrm{L}$ of the mixture thus prepared was moved to the second tube on ice and $100 \mu \mathrm{L}$ of acid detergent solution $(0.08 \mathrm{M} \mathrm{HCl}, 0.15$ $\mathrm{M} \mathrm{NaCl}, 0.1 \% \mathrm{v} / \mathrm{v}$ Triton X-100, $\mathrm{pH} 1.2$ ) was added. After exactly $30 \mathrm{sec}$ (without a light), $300 \mu \mathrm{L}$ of acridine orange (AO)-staining solution [6 $\mu \mathrm{g}$ AO (chromatographically purified) (Polysciences, Inc. - USA) per ml citrate buffer (0.037M citric acid, $0.126 \mathrm{M}$ Na2HPO4, $1.1 \mathrm{mM}$ EDTA disodium, $0.15 \mathrm{M} \mathrm{NaCl}, \mathrm{pH} 6.0]$ was added. The prepared sample was incubated 3 minutes on ice (without a light) then examined in flow cytometry; 5000 spermatozoa were evaluated in each sample.

\section{Statistical analysis}

Data are presented as the mean standard error of the mean (SEM). Analysis of variance (ANOVA) was used to assess differences among stages of buserelin acetate supplementation on all the semen characteristics. When the $\mathrm{F}$ ratio was significant $(\mathrm{P}<0.05)$, Duncan's multiple range test was used to compare treatment means. For statistical analysis of the results used Statistica 12.0 (Stat Soft, Poland).

\section{RESULTS}

The influence of buserelin acetate on the parameters of frozen/thawed semen, collected from Polish HolsteinFriesian bulls, was shown in Figures 1-3.

Figure 1 shows the positive effect of the addition of buserelin acetate to the semen of the bulls on its qualitative parameters. The addition of $2 \mu \mathrm{g} / \mathrm{mL}$ of the GnRH analogue significantly $(P<0.05)$ improved the percentage of live spermatozoa in the study samples by an average of $6.61 \%$. The remaining concentrations did not have a significant $(P>0.05)$ effect on sperm cell viability. However, the obtained mean results of the percentage of live sperm indicate their higher percentage about the control group. In semen supplemented with an additive containing $4 \mu \mathrm{g} / \mathrm{mL}$ buserelin acetate, the mean viability of spermatozoa was $42.26 \%$ and was $2.06 \%$ higher than the average percentage of live sperm in the control group. Similar observations were obtained in samples with the addition of $8 \mu \mathrm{g} / \mathrm{mL}$ (the average percentage of live sperm was $1.73 \%$ higher). The percentage of dead spermatozoa in the samples supplemented with the above supplement was significantly lower $(P<0.05)$ in the samples containing 2 and $4 \mu \mathrm{g} / \mathrm{mL}$ successively by $4.70 \%$ and $4.84 \%$ compared to the control group.

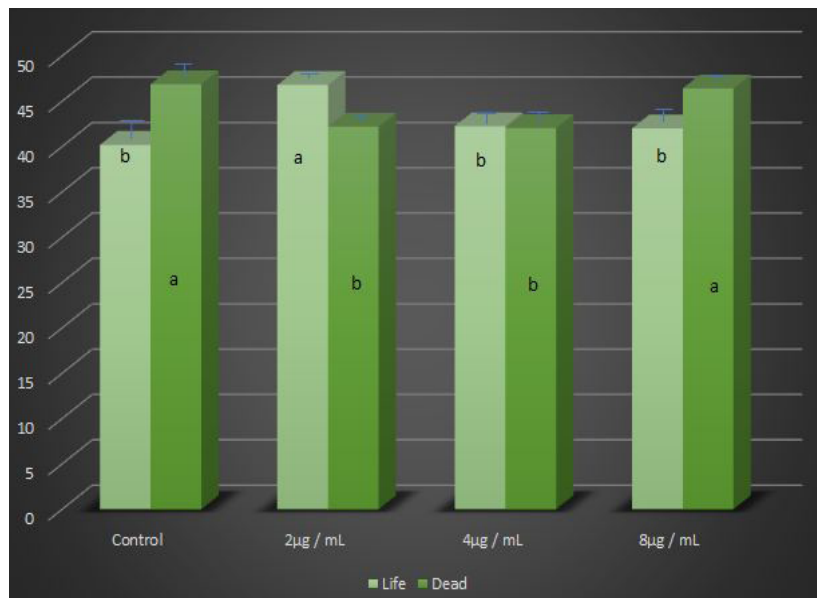

Fig. 1. Flow cytometry-obtained mean values of the viability from frozen-thawed bovine semen samples in the presence and the absence of buserelin acetate. Values are mean \pm S.D. of thawed bovine spermatozoa in all the concentration of buserelin acetate. Values in the same row with different letters mean significantly different $(\mathrm{P}$ $<0.05)$. $(\mathrm{n}=10)$.

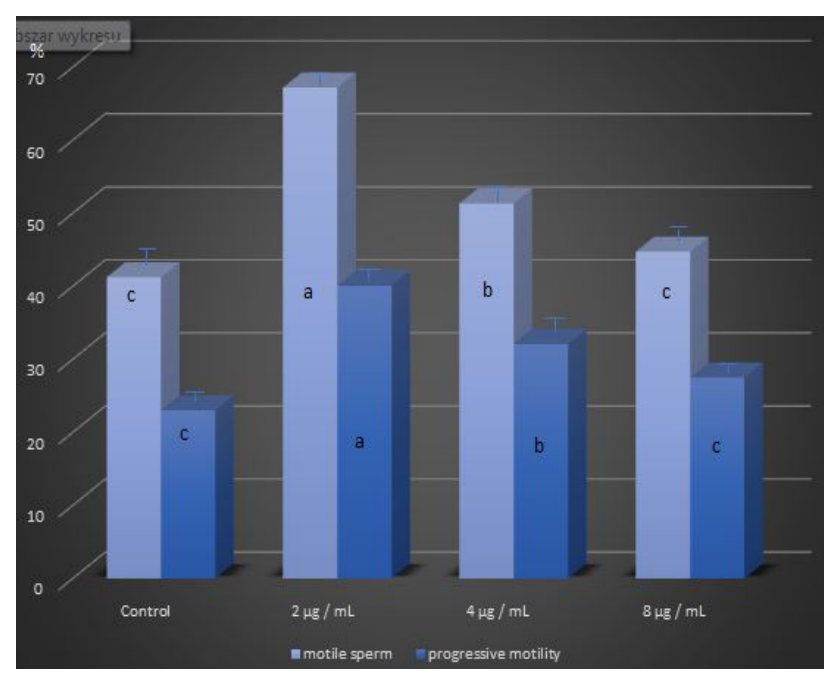

Fig. 2. CASA - obtained mean values of the percentage of motile sperm and progressive motility from frozen-thawed bovine semen samples in the presence and the absence of buserelin acetate. Values are mean \pm S.D. of thawed bovine spermatozoa in all the concentration of buserelin acetate. Values in the same row with different letters mean significantly different $(\mathrm{P}<0.05)$. $(\mathrm{n}=10)$. 


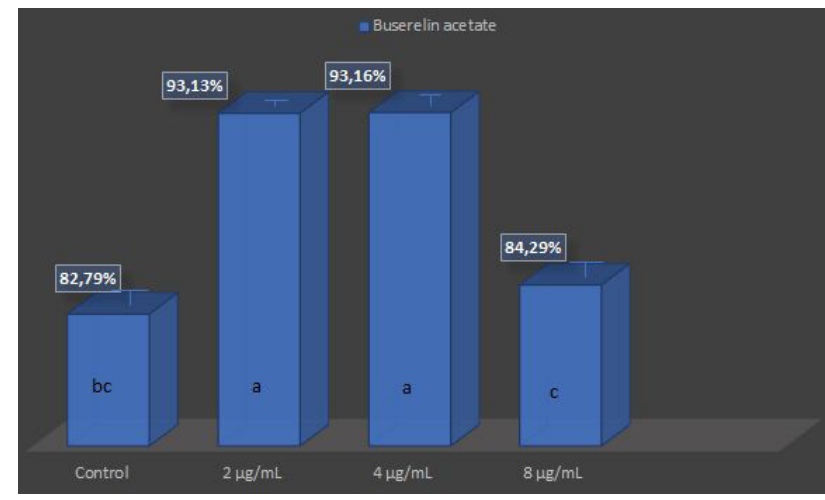

Fig. 3. Flow cytometry - obtained mean values of the DNA integrity from frozen-thawed bovine semen samples in the presence and the absence of buserelin acetate. Values are mean \pm S.D. of thawed bovine spermatozoa in all the concentration of buserelin acetate. Values in the same row with different letters mean significantly different $(\mathrm{P}<$ $0.05)$. $(\mathrm{n}=10)$.

Figure 2 shows the analysis of sperm motility. The obtained results indicate significant differences $(P<0.05)$ both in the progressive motility and the total sperm motility in the semen supplemented with the addition of 2 and $4 \mu \mathrm{g} / \mathrm{mL}$ buserelin acetate. The addition of $8 \mu \mathrm{g} / \mathrm{mL}$ did not significantly affect the semen parameters tested. Samples with the addition of $2 \mu \mathrm{g} / \mathrm{mL}$ reported the highest values of total sperm motility and progressive movement relative to the control group. The obtained results of total sperm motility in the samples supplemented with the addition of 2 and $4 \mu \mathrm{g} / \mathrm{mL}$ buserelin acetate were higher by $26.71 \%$ and $13.24 \%$ respectively. The progressive motility of spermatozoa in the samples with the addition of 2 and $4 \mu \mathrm{g} / \mathrm{mL}$ buserelin acetate was higher than the samples without the addition of an average of $17.79 \%$ and $9.81 \%$.

Figure 3 shows the analysis of the degree of DNA defragmentation in the test samples in the presence of buserelin acetate additive. Significant differences $(P$ $<0.05)$ were observed in semen supplemented with buserelin acetate at 2 and $4 \mu \mathrm{g} / \mathrm{mL}$. The average percentage of sperm with intact DNA in the samples with the addition of 2 and $4 \mu \mathrm{g} / \mathrm{mL} \mathrm{GnRH}$ analogue was higher by $10.33 \%$ and $10.36 \%$ than the samples without the additive $(82.79 \%)$. Samples with the addition of $8 \mu \mathrm{g} / \mathrm{mL}$ buserelin acetate did not report significantly higher results compared to the control group. However the average percentage of sperm with intact DNA was higher by $1.5 \%$.

\section{DISCUSSION}

The presented research results show a positive effect of buserelin acetate addition on the quality of bull semen. So far, the effect of GnRH analogues on sperm quality in cattle has not been studied. The action of analogues on sperm cells of other species is also not well known. Recent studies by Gogol et al. (2014) have shown a significant effect of the addition of the GnRH analogue to rabbit semen on sperm motility parameters, which is also confirmed by other studies (Mizera et al., 2018; Gogol and Wierzchoś-Hilczer, 2009; Gogol, 2013). In own studies, an improvement in the quality of total motility and progressive motility was also observed in samples supplemented with buserelin acetate.

In the presented studies, the protective action of buserelin acetate on sensitive sperm DNA structures has been demonstrated, and research shows that (Larson et al., 2000; Filatov et al., 1999) the degree of sperm DNA defragmentation plays a major role in early embryogenesis. DNA damage directly affects the overall quality of semen, which is confirmed by the results of studies by different authors (Gandini et al., 2000; Irvine et al., 2000). Thus, the possibility of optimizing the environment for storing male sperms to protect DNA against defragmentation is very valuable, if only from the correlation between DNA fragmentation and the effectiveness of fertilization (Tomlinson et al., 2001; Morris et al., 2002).

Sperm supplementation with the GnRH analogue (buserelin acetate) also showed protective effects on sperm cell membranes, thereby reducing the percentage of dead sperm and increasing the percentage of live and considering that the viability of sperm is one of the most important factors determining effective reproduction, the action of buserelin acetate can be classified as highly beneficial.

\section{CONCLUSION}

Improving the quality of frozen semen due to the use of GnRH analogue additive (buserelin acetate) for bovine semen and its low cost of use in routine semen production will allow manufacturers of insemination doses to improve the quality of their product. Moreover, the results of the above studies open up the field for further research on the possibility of combining insemination with semen supplemented with GnRH along with estrus induction or ovulation in cows. Undoubtedly, this is an interesting area for further research.

\section{Statement of conflicts of interest}

The authors report no conflicts of interest. 


\section{REFERENCES}

Filatov, M.V., Semenova, E.V., Vorob'eva, O.A., Leont'eva, O.A. and Drobchenko, E.A., 1999. Relationship between abnormal sperm chromatin packing and IVF results. Mol. Hum. Reprod., 5: 825-830. https://doi.org/10.1093/molehr/5.9.825

Gandini, L., Lombardo, F., Paoli, D., Caponecchia, L., Familiari, G., Verlengia, C., Dondero, F. and Lenzi, A., 2000. Study of apoptotic DNA fragmentation in human spermatozoa. Hum. Reprod., 15: 830-839. https://doi.org/10.1093/humrep/15.4.830

Garcia-Ispierto, I., Lopez-Helguera, I., Martinez, A. and Lopez-Gatius, F., 2012. Reproductive performance of anoestrous high-producing dairy cows improved by adding equine chorionic gonadotrophin to a progesterone-based oestrous synchronizing protocol. Reprod. Domest. Anim., 47: 752- 758. https://doi.org/10.1111/j.1439-0531.2011.01954.x

Garcia-Ispierto, I. and Lopez-Gatius, F., 2013. A three day PGF2a plus eCG-based fixed-- time AI protocol improves fertility over spontaneous estrus in dairy cows with silent ovulation. J. Reprod. Dev., 59: 393-397. https://doi.org/10.1262/jrd.2013-017

Garcia-Ispierto, I., Rosello, M.A., De Rensis, F. and Lopez-Gatius, F., 2013. A five-day proges- terone plus eCG-based fixed-time AI protocol improves fertility over spontaneous estrus in high-producing dairy cows under heat stress. J. Reprod. Dev., 59: 544- 548. https://doi.org/10.1262/jrd.2013-041

Gogol, P., 2015. Indukowanie owulacji u królików poprzez podanie analogu GnRH - desloreliny w dawce inseminacyjnej. Wiadomości Zootech., 53: $25-28$.

Gogol, P., 2013. Motility parameters and intracellular ATP content of rabbit spermatozoa stored for 3 days at 15o C. Folia Biol (Kraków), 61: 87-91. https://doi.org/10.3409/fb61_1-2.87

Gogol, P., 2016. Wskaźniki reprodukcyjne królików inseminowanych nasieniem $\mathrm{z}$ dodatkiem analogu gnrh[des-gly10, d-ala6]-lh-rh ethylamide. Rocz. Nauk. Zoot., 43: 199-204

Gogol, P., Trzcińska, M. and Bryła, M., 2014. Motility, mitochondrial membrane potential and ATP content of rabbit spermatozoa stored in extender supplemented with GnRH analogue [des-Gly10, D-Ala6]-LH-RH ethylamide. Polish J. Vet. Sci., 17:
571-575. https://doi.org/10.2478/pjvs-2014-0085

Gogol, P. and Wierzchoś-Hilczer, A., 2009. Membrane integrity, energy status and motility of rabbit spermatozoa stored for 2 days at 150 C. Annls Anim. Sci., 9: 43-49. https://doi.org/10.1016/ S1642-431X(12)60093-X

Irvine, D.S., Twigg, J.P., Gordon, E.L., Fulton, N., Milne, P.A. and Aitken, R.J., 2000. DNA integrity in human spermatozoa: Relationships with semen quality. J. Androl., 21: 33-44.

Larson, K.L., DeJonge, C.J., Barnes, A.M., Jost, L.K. and Evenson, D.P., 2000. Sperm chromatin structure assay parameters as predictors of failed pregnancy following assisted reproductive techniques. Hum. Reprod., 15: 1717-1722. https://doi.org/10.1093/ humrep/15.8.1717

Mizera, A., Kuczaj, M., Szul, A. and Jedraszczyk, J., 2018. Effect of addition of buserelin acetate to the extender on motility and viability of bovine spermatozoa. Anim. Biotech., https://doi.org/10.10 80/10495398.2018.1521821

Morris, I.D., Ilott, S., Dixon, L. and Brison, D.R., 2002. The spectrum of DNA damage in human sperm assessed by single cell gel electrophoresis (Comet assay) and its relationship to fertilization and embryo development. Hum. Reprod., 17: 990-998. https://doi.org/10.1093/humrep/17.4.990

Schulman, M.L., Botha, A.E., Muenscher, S.B., Annandale, C.H., Guthrie, A.J. and Bertschinger, H.J., 2012. Reversibility of the effects of GnRHvaccination used to suppress reproductive function in mares. Equine Vet. J., 45: 111-113. https://doi. org/10.1111/j.2042-3306.2012.00577.x

Souza, A.H., Viechneski, S., Lima, F.A., Silva, F.F., Araujo, R., Bo, G.A., Wiltbank, M.C., Baruselli, P.S., 2009. Effects of equine chorionic gonadotropin and type of ovulatory stimulus in timed-AI protocol on reproductive responses in dairy cow. Theriogenology, 72: 10-21. https://doi. org/10.1016/j.theriogenology.2008.12.025

Tomlinson, M.J., Moffatt, O., Manicardi, G.C., Bizzaro, D., Afnan, M. and Sakkas, D., 2001. Interrelationships between seminal parameters and sperm nuclear DNA damage before and after density gradient centrifugation: Implications for assisted conception. Hum. Reprod., 16: 2160-2165. https://doi.org/10.1093/humrep/16.10.2160 